\title{
INOVACIJŲ DIEGIMĄ LEMIANTYS VEIKSNIAI KLAIPE்DOS MIESTO TURIZMO SEKTORIUJE
}

\author{
Ida Meschi, Aurimas Župerka, Erika Župerkienė \\ Klaipédos universitetas
}

\begin{abstract}
Anotacija
Straipsnyje nagrinèjami veiksniai, darantys įtaką inovacijų diegimui Klaipėdos miesto sektoriuje. Aptariami globalūs pokyčiai, pastebimi ir Lietuvos turizmo sektoriuje. Atlikto giluminio interviu su ekspertais pagrindu išskirti veiksniai, trukdantys igyvendinti inovacijų diegimo planus turizmo sektoriaus įmonėse: finansavimo stoka, investuotojų pritraukimo problema, nekryptingai formuojama Klaipedos miesto turizmo politika, neparengta miesto turizmo strategija, nenustatyti jos prioritetiniai tikslai, nepakankamos pastangos pritraukiant turistus iš kaimyninių valstybių. Tyrimo rezultatų analizè parodè, kad, nepaisant išskirtų trūkumų, kaip labiausiai lemiantys inovacijų diegimą Lietuvos turizmo sektoriuje ịvardijami technologiniai veiksniai (IT technologijos), kurių pagrindu gali būti didinamas darbo našumas ir gerinama aptarnavimo kokybè.
\end{abstract}

PAGRINDINIAI ŽODŽIAI: inovacijos, inovacijų diegimas, turizmas, turizmo paslaugos, veiksniai.

\begin{abstract}
In the article there are analysed factors influencing implementation of innovations in Klaipeda city tourism sector. There are discussed the global changes noticeable in Lithuania tourism sector as well. On the basis of conducted in-depth interview with experts there are identified factors, which impede the realization of plans of implementation of innovations in enterprises of the tourism sector such as the following: lack of funding; the problem of attracting investors; unfocused tourism policy, formed in Klaipeda city; not prepared city tourism strategy and its underlying goals; insufficient efforts to attract tourists from neighboring countries. Analysis of the findings showed that with all identified failings there are named technological factors (IT technologies) as the most influencing factors determining implementation of innovations in Lithuania tourism sector, on the basis of which working efficiency may be enhanced and service quality may be improved.

KEY WORDS: innovations, implementation of innovations, tourism, tourism services, factors.
\end{abstract}

DOI: http://dx.doi.org/10.15181/tbb.v69i1.1054

\section{Ivadas}

Turizmas daugelyje šalių siejamas su šalies ekonominiais ir užimtumo veiksniais kuriant bendraji vidaus produktą bei tvarią vystymosi politiką. Turizmo įtaka šalies vidaus politikai (miestų ir miestelių plètrai, žemės ūkio vystymui, platesniam paslaugų panaudojimui geografiniu aspektu ar kasdienio vartojimo prekių gamybos apimčių didèjimui) lèmè naujas visuomenès požiūrio tendencijas: turizmas pradètas analizuoti ir vertinti kaip socioekonominès raidos katalizatorius, kuris užima prioritetinès ūkio veiklos pozicijas. Dẻl pasikeitusio visuomenès požiūrio ir 
naujų tendencijų pastaraisiais dešimtmečiais mokslinèje literatūroje turizmas pripažịstamas kaip viena pirmaujančių ir dinamiškiausių pasaulio ūkio veiklos rūšių. Atsižvelgiant ị tai, galima teigti, kad šiandieniame kontekste turizmas - plačiai paplitęs reiškinys ir svarbus ekonominę plètrą lemiantis veiksnys, siekiant iggyti konkurencini pranašumą tiek regioniniu, tiek globaliu mastu, taip pat išlaikyti, apsaugoti ar sustiprinti konkurencines pozicijas vis konkurencingesneje pasaulio rinkoje (Imali, Wei, 2012, p. 75). Inovacijų reikšmė turizmo versle išaugo išradus naujas informacijos ir komunikacijos technologijas, kurios ypač paveikè turizmo sektorių (Decelle, 2004, p. 3). Situacija Lietuvos turizmo sektoriuje - ne išimtis, siekiant išsilaikyti pasaulio konkurencinejje aplinkoje geriausia priemone - inovacijų diegimas.

Inovacijos dažnai apibūdinamos kaip kritinis sėkmės veiksnys turizme (Mayer, 2009, p. 124), tačiau beveik iki XXI a. pradžios jų svarba ir pasekmės turizmui buvo sunkiai numatomos ir retai analizuojamos. Nors inovacijų turizme tema pradèta nagrinèti devintojo dešimtmečio pabaigoje (Nagy, 2012, p. 367), o pastaraisiais metais padaryta gana didelė pažanga (Hjalager, 2002; Orfila-Sintes ir kt., 2005; Keller, 2005; Pikkemaatand, Weiermair, 2007; Sundbo ir kt. 2007), akademinèje literatūroje publikacijų šia tema aptinkama stebètinai nedaug. Visgi, pasak J. Fagerberg, D. C. Mowery ir R. R. Nelson (2005, p. 2), pastebima, kad per pastaruosius kelis dešimtmečius socialinių mokslų srities publikacijų apie inovacijas skaičius augo daug sparčiau nei bendras publikacijų skaičius. Inovacijų tyrimu tarpdiscipliniškumas, tiriant inovacijas iš įvairių perspektyvų, rodo ne tik didejjantị poreikị analizuoti inovacijas, bet ir mokslinių tyrimų problemų kompleksiškumą.

Straipsnyje nagrinejama problema: kokie veiksniai šiuo metu aktualiausi Klaipėdos miesto turizmo sektoriaus vystymui.

Objektas - veiksniai, lemiantys inovacijų diegimą.

Tikslas: įvardyti veiksnius, kurie lemia inovacijų diegimą Klaipėdos miesto turizmo sektoriuje.

Uždaviniai: apibrèžti inovacijų diegimo vaidmenị turizmo sektoriuje; išskirti veiksnius, kurie trukdo diegti inovacijas turizmo sektoriuje; ịvardyti veiksnius ir sąlygas, kurios padeda sukurti inovacijų diegimui turizmo sektoriuje palankią aplinką.

Metodai: mokslinès literatūros analizès, sisteminimo, apibendrinimo ir palyginimo. Siekiant apibendrinti ir palyginti teorinius teiginius ir padaryti išvadas, taikyta loginè analizè. Renkant informaciją apie inovacijų diegimą lemiančius veiksnius Klaipedos miesto turizmo sektoriuje, taikytas giluminis interviu. 


\section{Inovacijų diegimo vaidmuo turizmo sektoriuje}

Viena vertus, turizmas - labai dinamiškas sektorius, stipriai veikiamas pasaulinès konkurencijos ir pasižymintis nuolatine transformacija (Meneses, Texeira, 2011, p. 26). Kita vertus, turizmas yra sudètinga sistema, kur turistai, geografiniai elementai ir turizmo verslo subjektai yra integruoti ir priversti sąveikauti tarpusavyje ịvairiose aplinkose (Holden, 2003). Visgi konkurencija tarp organizacijų turizmo sektoriuje yra labai didelè. Ji dažnai išryškejja tarp organizacijų, atliekančių tas pačias funkcijas, kartu organizacijos bendradarbiauja, siekdamos ịgyti pranašumą vietovių lygmeniu, visa tai ir dar daugiau lemia turizmo sektoriaus vaidmenị šalyje.

Turizmo sektorius apima ne tik aptarnavimo sriti, bet ir kitas valstybės veiklos sritis (transporto sistemą, vidaus rinką, mokesčius, aplinkos, užimtumo, kultūros, regioninès ir kaimo plètros tikslus ir pan.). Todèl ypač svarbu, kad diegiant inovacijas būtų atsižvelgiama ị turizmo verslo poreikius ir tinkamą jų igyvendinimą. Siekdamos išlikti konkurencingos rinkoje, kaip ir kitose gamybos pramonés ar paslaugų sektoriaus šakose, turizmo įmonès privalo nuolat diegti inovacijas, priešingu atveju įmonès siūlomas produktas ar paslauga gali būti pakeisti naujais, konkurentų siūlomais produktais ar paslaugomis ir nebeturèti paklausos. Inovacijų diegimas turizmo sektoriuje dažnai padidina konkurenciją tarp šio sektoriaus atstovų, darbo našumą ar pagerina aptarnavimo kokybę. Kita vertus, turizmo sektoriaus funkcijos turizmo įmonėms kelia ambicingus iššūkius (Meneses, Texeira, 2011, p. 27). Diegiant inovacijas turizmo sektoriuje orientacija ị klientą atlieka svarbiausią vaidmenį, todèl pastebima, kad sẻkmingiausios turizmo įmonės laikosi nuolatinio prisitaikymo prie paklausos pokyčiu principų. Nemažiau svarbus yra naujų darbo vietų skaičiaus augimas, ypač aktualus sparčiai augančios ekonomikos šalyse. Brandaus turizmo ekonomikoje inovacijų diegimas taip pat gali būti vienas iš būdų, siūlantis naujus ir kokybiškus produktus ar paslaugas ir taip padedantis konkuruoti su naujomis rinkomis.

R. Daugèlienès ir A. Brundzos (2009, p. 180) teigimu, pastaruoju metu pasauliniame turizmo sektoriuje pastebimi tokie pokyčiai kaip veiklos specializacijos skatinimas, sparti technologijų raida ir turizmo paslaugų vartotojų globalizacija, nors ir yra sudètingi, turètų būti teigiamai vertinami dẻl turizmo paslaugų teikèjų suteikiamų naujų galimybių klientams lankstumo. Tai reiškia, kad diegiant inovacijas turizmo sektoriaus įmonèms nebūtina kardinaliai keisti savo profilio, tam užtenka tiesiog lankstumo. Nors pagrindiniai pokyčiai ir inovacijos turizmo sektoriuje susiję su informacinių ir ryšio technologijų taikymu (pvz., informacinių ir ryšio technologijų sklaida turizmo sektoriuje leidžia vartotojams paprasčiau nei kadaise tiesiogiai bendrauti su turizmo paslaugų teikejjais [Korres, 2008, p. 13]), inovacijų diegimas turizmo sektoriuje gali pasireikšti įvairiais aspektais: nuo naujų 
produktų ar paslaugų dizaino iki modernių šalies pristatymo metodų plètros. Esminiai inovacijų diegimo turizmo sektoriuje principai yra šie:

- aktyvi veikla, novatoriškų idejų generavimas ir diegimas turizmo sektoriuje ne tik verslo, bet ir nacionaliniu lygmeniu;

- naujų rizikingų įmonių kūrimas, inovatyvių renginių, projektų ir kitos veiklos rengimas padedant atkreipti dèmesị ir paskatinti kurti bei skleisti inovacijas turizmo sektoriuje;

- kūrybiškumo skatinimas, siekiant perpozicionuoti turizmo produktą ar paslaugas ir jų principus;

- socialinès atsakomybès diegimas, siekiant paskatinti prisiimti atsakomybę ir ịsipareigojimus už tiriamają inovacinę veiklą bei jos rezultatus, tai įmanoma tik esant dialogui tarp turizmo sektoriaus atstovų ir visuomenès;

- dinamiškumo išlaikymas suaktyvejjusių pokyčių, t. y. atsinaujinimo, tobulinimo ir efektyvumo didinimo, kontekste.

Kaip pastebèjo kai kurie autoriai (Sapiegienė, Juknevičienė, Stoškus, 2009, p. 237), nepaisant inovacijų diegimo galimybių turizme, Lietuvos inovacinės veiklos rodikliai buvo vieni žemiausių Europos Sajungoje (toliau - ES), o Lietuvos ịmonių konkurencingumas pastarajị dešimtmetị daugiausia priklausė nuo santykinai pigių gamybos veiksnių, vidaus investicijų, sparčių vietos išnaudojimo ir eksporto augimo tempų. Tačiau lyginant 2013 m. duomenis su $2011 \mathrm{~m}$. duomenimis, situacija visiškai pasikeitè: Lietuva, kartu su kitomis ES šalimis (Čekija, Graikija, Vengrija, Italija, Malta, Portugalija, Slovakija ir Ispanija) iš kuklių inovatorių grupès pakilo ì nuosaikių inovatorių grupę (European Commission, Innovation Union Scoreboard, 2013, p. 10), šios pozicijos nepasikeitė ir kitais metais (European Commission, Innovation Union Scoreboard, 2014, p. 5). Kuklių inovatorių kategorijai priklauso šalys, kurių novatoriškumo indeksas yra daugiau nei $50 \%$ žemesnis už vidutini ES narių novatoriškumo indeksą, tuo tarpu nuosaikių inovatorių kategorijai priklauso šalys, kurių novatoriškumo indeksas yra nuo 10 \% iki 50 \% žemesnis už bendrą ES novatoriškumo indeksą.

Iš pateiktų duomenų galima daryti išvadą, kad siekiant patekti ị nuosaikių novatorių grupę inovacijų diegimas, kaip konkurencingumo skatinimo priemonė, Lietuvoje tapo prioritetine kryptimi. Kadangi turizmas - viena labiausiai augančių šalies ūkio sričių, galima teigti, kad svarbiausią vaidmenị, lemiant turizmo augimą, vaidina inovacijų diegimas.

\section{Giluminio interviu su ekspertais tyrimo rezultatų analizė}

Turizmo sektorius apibrēžiamas pagal Europos ekonominès veiklos rūšių klasifikatoriaus (toliau - EVRK) veiklas (Ekonominès veiklos rūšiu klasifikatorius, 
2 redakcija), pagal kurias analizuojamą sektorių sudaro trys subsektoriai: apgyvendinimo įmonès (toliau - AP), t. y. 55.1 (viešbučių ir panašių laikinų buveinių) bei 55.2 (poilsiautojų ir kita trumpalaikio apgyvendinimo) veiklos, sveikatingumo ịmonès (toliau - SV), kelionių agentūros ir ekskursijų organizatoriai (toliau-KE), t. y. 79.1 veikla (EVRK). Panašiai klasifikuojamos ir turizmo paslaugų rūšys (Lietuvos Respublikos turizmo įstatymas, 2011):

1) kelionių organizavimo paslaugos;

2) turistų informavimo paslaugos;

3) apgyvendinimo paslaugos;

4) sveikatinimo ir sveikatingumo paslaugos;

5) vežimo, maitinimo, pramogų, vandens ir kt. turizmo paslaugos.

Lietuvos statistikos departamento duomenimis, $2012 \mathrm{~m}$. Lietuvos turizmo sektoriuje veikè 1959 įmonès. Daugiau nei pusé visų šių ịmonių, net 53 proc. (1032 vnt.), specializavosi AP subsektoriuje, 30 proc. (605 vnt.) - SV subsektoriuje, 17 proc. (322 vnt.) - KE srityse (Lietuvos statistikos departamentas, 2013, p. 25, 46, 59). Lyginant su 2011 m., i̇monių skaičius subsektoriuose kito atitinkamai: $-6,8 \%-\mathrm{AP},+1 \%-\mathrm{SV},+2,5 \%-\mathrm{KE}$ (11 pav.). Kalbant apie AP ir KE subsektorius, didžiausia turizmo įmonių koncentracija pastebima Klaipėdos, Vilniaus ir Kauno apskrityse. Didžioji dalis SV subsektoriui priklausančių įmonių veiklą vykdo Utenos, Vilniaus ir Alytaus apskrityse.

Inovacijų diegimą lemiančių veiksnių tyrimui Klaipėdos apskrities turizmo sektoriuje pasirinktas kokybinis tyrimas - giluminis interviu su ekspertais. Tyrime dalyvavo 9 Klaipèdos apskrities turizmo sektoriaus ekspertai, iš kurių 4 asmenys atstovavo kelionių agentūroms ir ekskursijų organizatoriams (KE), 5 asmenys - apgyvendinimo subsektoriaus (AP) įmonėms. Apklaustų ekspertų įmonėse darbuotojų skaičius svyruoja nuo 9 iki 294, tai reiškia, kad interviu buvo atliekamas su smulkiu ir vidutinių įmonių atstovais. Kalbant apie ekspertų charakteristiką, galima paminèti, kad 6 iš 9 interviu dalyvavusių ekspertu šiuo metu užima direktoriaus (-ès), 1 - plètros direktoriaus (-ès), 1 - komercijos direktoriaus (-ès) ir 1 - pardavimu vadovo (-ès) pareigas Klaipèdos miesto KE ir AP paslaugas teikiančiose įmonèse. Atsižvelgiant ị respondentų einamas pareigas, didesnę nei 3 metų patirtị dirbant turizmo sektoriuje ir segmentą, kuriam atstovavo ekspertai, galima teigti, kad ekspertų atsakymai ị klausimus yra patikimi, objektyvūs ir atskleidžia rinkos situaciją.

Interviu su ekspertais rezultatų analizè atskleidè, kad nepaisant pastebimų trūkumų diegiant inovacijas Lietuvos turizmo sektoriuje, dauguma apklaustujų sutinka, kad IT inovacijų diegimas Lietuvos turizmo sektoriuje didina darbo našumą ir gerina aptarnavimo kokybę, jie taip pat pabrèžia, jog IT inovacijų diegimą įmonès viduje bei Lietuvos turizmo sektoriuje vertina teigiamai. Atlikti tyrimai padejo 
ịvertinti inovacijų poreikị Klaipėdos miesto turizmo sektoriuje. Ekspertų teigimu, jų atstovaujamose įmonèse taikomos tokios IT inovacijos:

- išmaniujų ịrenginių (nešiojamųjų kompiuterių, planšečių, išmaniųjų telefonų) naudojimas darbinèje veikloje;

- viešbučių kambarių rezervavimo sistema, kuri leidžia stebėti viešbučio užimtumą;

- $\quad$ socialinių tinklų naudojimas trumpalaikiams pasiūlymams paskelbti;

- QR kodų naudojimas;

- mobiliosios aplikacijos ir jų integravimas su viešbučio kambarių rezervavimo sistema;

- viešbučių restoranų apskaitos sistemos „R-keeper“;

- papildomi moduliai, leidžiantys suderinti užsienietiškas programas su lietuviškomis;

- belaidžio interneto prieiga (Wi-Fi) apgyvendinimo zonose;

- internetinių užsakymų prièmimo sistema;

- tam tikrų paslaugu grupių sujungimas viename internetiniame puslapyje (kelionių bilietų, viešbučių, vežimo paslaugų rezervavimo sistema).

Akivaizdu, kad tarp išvardytų IT inovacijų, kurios diegiamos Klaipėdos miesto KE ir AP subsektoriuose, trūksta turizmo sektoriaus vartotojų išreikštus poreikius atitinkančiu paslaugų bei produktų, kurie remtųsi informacinėmis technologijomis, būtų kompiuterizuoti, t. y. trūksta mobiliųų aplikacijų ir virtualių erdvių.

Keista, kad ekspertams interviu metu uždavus klausimą, ,kokio pobūdžio inovacijas planuojate diegti Jūsų įmonèje“, atsakymas buvo vienareikšmiškas: „Artimiausiu metu inovacijų diegti neplanuojam." Atsižvelgiant ị tokius atsakymų rezultatus, natūralu, kad atsakymai ị kitą klausimą puikiai iliustravo, kas trukdo igyvendinti inovacijų diegimo planus ekspertų atstovaujamose įmonèse. Pagrindinès ekspertų ịvardytos priežastys yra:

- nepakankamai lèšų skiriama turizmo veiklos plètojimui - finansavimo sto$\mathrm{ka}$;

- būtinos didelès finansinès, laiko ir žmogiškujų išteklių investicijos;

- investuotojų pritraukimo problema;

- nekryptingai kuriama Klaipédos miesto turizmo politika;

- neparengta miesto turizmo strategija, nenumatyti jos prioritetiniai tikslai;

- nesiorientuojama ị kaimyninių valstybių turistų rinkas;

- menka informacijos apie inovacijų diegimo galimybes sklaida;

- paramos smulkiam ir vidutiniam verslui stoka (šiam segmentui priklauso dauguma turizmo paslaugas teikiančių i̇monių;

- lietuvių mentalitetas riboja saviraiškos, kartu ir inovatyvių idejų sklaidos laisvę. 
Minèti veiksniai sutampa su tais, kuriuos respondentai įvardijo (1 lentelè) uždavus klausimą, „,kaip manote, kokie svarbiausi diegti inovacijas trukdantys veiksniai Lietuvos turizmo sektoriuje?“

1 lentele. Veiksniai, trukdantys Lietuvos turizmo sektoriuje diegti inovacijas

\begin{tabular}{|c|c|}
\hline Respondentai & Atsakymai \\
\hline $\begin{array}{l}\text { Respondentas } \\
\text { Nr. } 1\end{array}$ & $\begin{array}{l}\text { „...veiklos vystymui trūksta vizualizacijos, virtualizacijos, ypač } \\
\text { vaikams, ir kitų IT sprendimų, nes IT vis dar gali būti nauja, o kol sritis } \\
\text { nauja - ji įdomi...“ }\end{array}$ \\
\hline $\begin{array}{l}\text { Respondentas } \\
\text { Nr. } 2\end{array}$ & $\begin{array}{l}\text { „...istatyminės bazès prièmimas, neatsižvelgiant ị verslo poreikius ir } \\
\text { galimybes...“ }\end{array}$ \\
\hline $\begin{array}{l}\text { Respondentas } \\
\text { Nr. } 3\end{array}$ & $\begin{array}{l}\text { „Visų pirma, manau, jog pagrindiniai inovacijų diegimui trukdantys } \\
\text { veiksniai yra įmonių darbuotojų kompetencija ir pasipriešinimo reakcija } \\
\text { ị inovacijų diegimą. Taip pat greitai kintantys šiuolaikinès visuomenès } \\
\text { poreikiai, finansavimas ir įmonių bendradarbiavimo stoka“ }\end{array}$ \\
\hline $\begin{array}{l}\text { Respondentas } \\
\text { Nr. } 4\end{array}$ & $\begin{array}{l}\text { „...netolygus paslaugų konkurencingumas, lyginant su kaimyninėmis } \\
\text { rinkomis, potencialių rinkų praradimas dèl paslaugų kainodaros } \\
\text { nuokrypių““ }\end{array}$ \\
\hline $\begin{array}{l}\text { Respondentas } \\
\text { Nr. } 5\end{array}$ & $\begin{array}{l}\text { „Inovacijų diegimui trukdo tai, kad didžiają paslaugų teikèjų dali } \\
\text { rinkoje sudaro turizmo versle vyraujančios mažos įmonès, kurios neturi } \\
\text { finansinių išteklių diegti naujoves, dažnai dėl kompetencijos stokos } \\
\text { negeba panaudoti jau esamų inovacijų“ }\end{array}$ \\
\hline $\begin{array}{l}\text { Respondentas } \\
\text { Nr. } 6\end{array}$ & $\begin{array}{l}\text { „...menka informacijos apie inovacijų diegimo galimybes sklaida, } \\
\text { nes visa informacija apie inovacijas dažniausiai pasiekia mus iš } \\
\text { vartotojo lūpų. Visa informacija, pateikiama nacionalinių renginių ar } \\
\text { konferencijų metu, iki regionų ateina kur kas vėliau, tad ką, kur ir kaip } \\
\text { tikslingai sukurti vartotojui ir ịgyvendinti, trūksta žinių, gal tam reikėtų } \\
\text { periodinių mokymų...“ }\end{array}$ \\
\hline $\begin{array}{l}\text { Respondentas } \\
\text { Nr. } 7\end{array}$ & $\begin{array}{l}\text { „Pagrindinis trukdis diegiant inovacijas - turizmo inovacijų sistemos } \\
\text { plètra, kuri turètų būti įtraukta ị regioninę, nacionalinę ir tarptautinę } \\
\text { politiką, apimant ịvairius politinius, kooperacinius ir žmogiškuosius } \\
\text { elementus, siekiant palengvinti turizmo plètrą ir skatinti turizmo } \\
\text { verslą“ }\end{array}$ \\
\hline $\begin{array}{l}\text { Respondentas } \\
\text { Nr. } 8\end{array}$ & $\begin{array}{l}\text { „Kaip svarbiausius įvardinčiau bendros turizmo politikos ir strategijos } \\
\text { nebuvimą bei finansinius veiksnius“ }\end{array}$ \\
\hline $\begin{array}{l}\text { Respondentas } \\
\text { Nr. } 9\end{array}$ & $\begin{array}{l}\text { „Turizme vyrauja mažos ir nedidelès ịmonès, kurioms surasti } \\
\text { investitorius ar pritraukti investicijas kitais būdais - sudètingiau nei } \\
\text { didelėms įmonėms“ }\end{array}$ \\
\hline
\end{tabular}

Šaltinis: sudaryta remiantis tyrimo rezultatais.

Apibendrinant tyrimo rezultatus galima išskirti veiksnius, kurie trukdo igyvendinti inovacijų diegimo planus turizmo sektoriaus įmonėse: finansavimo stoka, investuotojų pritraukimo problema, nekryptingai formuojama Klaipèdos miesto 
turizmo politika, neparengta miesto turizmo strategija, nenumatyti jos prioritetiniai tikslai, nepakankamos pastangos pritraukiant turistus iš kaimyninių valstybių.

Uždavus respondentams klausimą, „kokie turizmo sektoriaus įmonių veiksmai, Jūsų nuomone, būtų veiksmingi, siekiant užtikrinti palankią aplinką inovacijų diegimui turizme?“, ekspertai pateikè nuomones (2 lentelè), kad pagrindiniai veiksmai turètų būti susiję su: vartotojų poreikius atitinkančių produktų ir paslaugų paieška, konkurentų teikiamų paslaugų rinkoje analize, naujų paslaugų ir rinkų plètros galimybių paieška, dalinimusi geraja patirtimi su kitais turizmo sektoriaus atstovais, sinergijos ir klasterizavimo galimybių paieška.

2 lentelè. Pageidaujamos inovacijų diegimo turizmo sektoriuje sąlygos

\begin{tabular}{|c|c|}
\hline Respondentai & Atsakymai i klausimą \\
\hline $\begin{array}{l}\text { Respondentas } \\
\text { Nr. } 1\end{array}$ & $\begin{array}{l}\text { „Mokymų, seminarų, išvykų ị užsienio valstybes organizavimas, siekiant } \\
\text { pasidalinti geraja patirtimi, pasisemti pavyzdžių ir idèjų iš kitų turizmo } \\
\text { sektoriaus atstovų“ }\end{array}$ \\
\hline $\begin{array}{l}\text { Respondentas } \\
\text { Nr. } 2\end{array}$ & $\begin{array}{l}\text { „Naujų paslaugų ir rinkų plètros galimybių paieška - reikia atlikti } \\
\text { rinkos tyrimus, išsiaiškinti vietinių ir užsienio turistų poreikius. Taip pat } \\
\text { išanalizuoti rinkos situaciją, konkurentų galimybes ir panaudojant IT } \\
\text { ieškoti rinkodarinių sprendimų“ }\end{array}$ \\
\hline $\begin{array}{l}\text { Respondentas } \\
\text { Nr. } 3\end{array}$ & $\begin{array}{l}\text { „...teikti pasiūlymus turizmo politikos formavimo specialistams, turizmo } \\
\text { ivaizdžio formavimo atstovams...“ }\end{array}$ \\
\hline $\begin{array}{l}\text { Respondentas } \\
\text { Nr. } 4\end{array}$ & $\begin{array}{l}\text { „...ieškoti galimybių investitorių pritraukimui ir rodyti iniciatyvą bendrų } \\
\text { inovatyvių projektų igyvendinimui...“ }\end{array}$ \\
\hline $\begin{array}{l}\text { Respondentas } \\
\text { Nr. } 5\end{array}$ & „...konkurentų teikiamų paslaugų rinkoje analizé...“ \\
\hline $\begin{array}{l}\text { Respondentas } \\
\text { Nr. } 6\end{array}$ & $\begin{array}{l}\text { „Veiksmai: didinti kultūros institucijų darbuotojų IT panaudojimo } \\
\text { kompetencijas, ugdyti jų kūrybiškumą; skatinti bendradarbiavimą tarp } \\
\text { îvairių sektorių organizacijų; skirti pakankamą finansavimą“ }\end{array}$ \\
\hline $\begin{array}{l}\text { Respondentas } \\
\text { Nr. } 7\end{array}$ & $\begin{array}{l}\text { „Inovacijų diegimui turizme padètų vartotojų poreikius atitinkančių } \\
\text { produktų ir paslaugų paieška, t. y. reikia sukonkretinti, ko vartotojai nori, } \\
\text { tik tuomet apsibrezžti, kokias IT priemones, technologijas verta pasirinkti, } \\
\text { siekiant realizuoti poreikius“ }\end{array}$ \\
\hline $\begin{array}{l}\text { Respondentas } \\
\text { Nr. } 8\end{array}$ & $\begin{array}{l}\text { „Itin svarbus veiksnys - santykiai su verslo partneriais ir kitais tarpininkais } \\
\text { turizmo aplinkoje, kas leistų lengviau pasinaudoti informacija apie } \\
\text { industrijos plètrą, galimas nesèkmes ir palankias progas“" }\end{array}$ \\
\hline $\begin{array}{l}\text { Respondentas } \\
\text { Nr. } 9\end{array}$ & $\begin{array}{l}\text { „Manau, reikia klasterizuotis ir daryti bendrą SPA, apgyvendinimo ir kitų } \\
\text { turistinių paslaugų rezervacijų, informacijos sistemą. Ieškant sinergijos } \\
\text { padidètų finansiniai ir žmogiškieji, inovatyvioms idejoms reikalingi } \\
\text { ištekliai. Klasteriai taip pat skatina mažų / vidutinių įmonių augimą ir } \\
\text { investicijų pritraukimą“ }\end{array}$ \\
\hline
\end{tabular}

Šaltinis: sudaryta remiantis tyrimo rezultatais. 
Dauguma respondentų inovacija laiko tai, kas jau egzistuoja, yra naudojama, pakeitė vartotojų ịpročius ir suteikè naujų galimybių, didelị dėmesi jie skiria ir finansiniam aspektui, IT inovacijų diegimo svarbą vertina atsižvelgdami ị tai, kiek pastarosios leidžia vartotojams sutaupyti.

Tyrimo ekspertai inovacijų diegimo aplinką Lietuvoje vertina teigiamai, vyrauja nuomonè, kad inovacijų diegimas turizmo srityje turi būti susijęs su informacinėmis technologijomis, kompiuterizacija, internetinių įrankių kūrimu ir jų naudojimu, mobiliosiomis aplikacijomis, virtualių erdvių kūrimu. Ekspertai išsakè nuomonę, kad inovacijų diegimą turizme turètų skatinti: 1) patys turizmo sektoriaus atstovai (turizmo informacijos centrai, turizmo paslaugas teikiančios įmonés ir kt.); 2) Vyriausybė; 3) prie IT inovacijų diegimo skatinimo Lietuvos turizmo sektoriuje turètų prisidèti ir turizmo paslaugų vartotojai. Analizuojant inovacijų diegimą Klaipédos mieste turizmo sektoriaus ekspertai patvirtino, kad tarp įdiegtų IT inovacijų, kurios naudojamos Klaipedos miesto KE ir AP subsektoriuose, trūksta turizmo sektoriaus vartotojų išreikštus poreikius atitinkančių paslaugų ir produktų, kurie remtųsi informacinèmis technologijomis, būtų kompiuterizuoti, t. y. trūksta mobiliujų aplikacijų ir virtualių erdvių.

\section{Išvados}

Inovacijų diegimas, kaip viena veiksmingiausių konkurencingumo skatinimo priemonių, yra prioritetinè kryptis Lietuvoje, todèl inovacinė veikla turizmo sektoriuje sudaro teigiamas prielaidas turizmo plètrai ir konkurencingumui.

Veiksniai, labiausiai trukdantys iggyvendinti inovacijų diegimo planus turizmo sektoriaus įmonėse, yra šie: finansavimo stoka, investuotojų pritraukimo problema, nekryptingai kuriama Klaipedos miesto turizmo politika, neparengta miesto turizmo strategija, nenumatyti jos prioritetiniai tikslai, nepakankamai pastangų dedama, siekiant pritraukti turistus iš kaimyninių valstybių.

Ryškiausiai išskiriamas technologinių veiksnių poveikis diegiant inovacijas turizmo sektoriuje, pabréžiama, kad inovacijų diegimas turizmo srityje turi būti susijęs su informacinèmis technologijomis, kompiuterizacija, internetinių įrankių kūrimu ir jų panaudojimu, mobiliosiomis aplikacijomis, virtualių erdvių kūrimu. Kuriant palankias inovacijų diegimo turizmo sektoriuje sąlygas ịvardijami dar ir kiti rinkos dalyvių poreikiai, kaip: mokyti turizmo sektoriaus darbuotojus, tirti vartotojų poreikius ir analizuoti konkurencinę padètí, glaudžiau bendradarbiauti su 
Ida Meschi, Aurimas Župerka, Erika Župerkienè

verslo partneriais tiek šalyje, tiek užsienyje, kurti bendras informacines sistemas, turizmo verslo klasterius.

Gauta 20150220

Pasirašyta spaudai 20150317

\title{
Literatūra
}

Daugèlienè, R., Brundza, A. (2009). Theoretical possibilities of expression of innovation in tourism sector: the case of Scotland and Slovenia. European integration studies: research and topicalities, No. 3: 176-183.

European Commission. (2013). Innovation Union Scoreboard 2013. European Commission, Brussels, 76 p.

European Commission. (2014). Innovation Union Scoreboard 2014. European Commission, Brussels, 94 p.

Fagerberg, J., Mowery, D. C., Nelson, R. R. (2005). The Oxford Handbook of Innovation. New York: Oxford University Press.

Hjalager, A. M. (2002). Repairing innovation defectiveness in tourism. Tourism Management, Vol. 23 (5): $465-$ 474.

Holden, A. (2003). Environment and tourism. London: Routledge.

Keller, P. (2005). Innovation in tourism - creating customer value. Innovation in tourism - creating customer value, No. 47: 7-20.

Korres, G. M. (2008). The Role of Innovation Activities in Tourism and Regional Growth in Europe. Tourismos: an International Multidisciplinary Journal of Tourism. University of the Aegean, Vol. 3 (1): 135-152.

Mayer, M. (2009). Innovation as a success factor in tourism: empirical evidence from western Austrian cable-car companies. Erdkunde, Vol. 63 (2): 123-139.

Meneses, O., Texeira, A. C. (2011). The innovative behaviour of tourism firms. An International Journal of Economics and Management Research Projects, Vol. 1 (1): 25-35.

Nagy, A. (2012). A Review of Tourism and Hospitality Innovation Research. Annals of Faculty of Economics, Vol. 1 (2): 364-370.

Orfila-Sintes, F., Crespi-Cladera, R., Martinez-Ros, E. (2005). Innovation activity in the hotel industry: evidence from Balearic Islands. Tourism Management, No. 26: 851-865.

Pikkemaat, B., Weiermair, K. (2007). Innovation through Cooperation in Destinations: First Results of an Empirical Study in Austria. An International Journal of Tourism and Hospitality Research “Anatolia”, Vol. 18 (1): 67-83.

Sapiegienė, L., Juknevičienė, V., Stoškus, S. (2009). Inovacijų diegimo procesas: Šiaulių miesto gamybos įmonių atvejų analizè. Ekonomika ir vadyba: aktualijos ir perspektyvos, Nr. 2 (15): 237-249.

Sundbo, J., Orfila-Sintes, F., Sorensen, F. (2007). The innovative behaviour of tourism firms - comparative studies of Denmark and Spain. Research Policy, Vol. 36: 88-106.

\section{FACTORS INFLUENCING IMPLEMENTATION OF INNOVATION IN KLAIPE்DA CITY TOURISM SECTOR}

\author{
Ida Meshi, Aurimas Župerka, Erika Župerkienė
}

Summary

Tourism in many countries is related with economical and employment factors while creating gross domestic product and policy of sustainable development. 
Impact of tourism on domestic policy (on development of cities and towns, agricultural growth, wider use of services from geographical approach or development of production of daily consumer goods) determined formation of new tendencies of public attitudes towards tourism - tourism was started to analyse and evaluate as catalyst of the socio-economic development, occupying position of leading economic activity. In recent decades due to changes in public attitudes toward tourism and newly formed trends tourism in the scientific literature is recognized as one of the leading and the world's most dynamic activities.

Innovation in tourism is relatively a new topic, but recent studies in this field are increasing. Interdisciplinary character of innovation studies, while investigating innovation from a variety of perspectives, display not only the increasing need to analyze the innovation but also a great complexity of the scientific research problems.

The problem, which is analyzed in the article - what factors are currently the most relevant for development of Klaipeda city tourism sector.

Object of research - factors, influencing implementation of innovations.

Aim - to identify factors, influencing implementation of innovations in Klaipéda city tourism sector.

Goals - to define the role of innovation in the tourism sector; to identify factors, which impede the implementation of innovations in the tourism sector; to identify factors and conditions creating a favorable environment for innovations implementation in the tourism sector.

Methods - analysis of scientific literature, systematization, generalization and comparison. In order to summarize and compare the theoretical statements and draw conclusions there was applied logical analysis. While gathering information about the factors influencing implementation of innovation in Klaipeda city tourism sector there was applied in-depth interview.

For investigation of factors, influencing implementation of innovation in Klaipeda district tourism sector there was chosen a qualitative research - in-depth interview with experts. 9 experts from Klaipeda district tourism sector participated in research: 4 of them represented travels agencies and tour operators (KE) and 5 of them - enterprises of accommodation sub-sector (AP). Number of enterprises employees, surveyed by experts, is ranging from 9 to 294, it means that the interview was conducted with representatives of small and medium-sized business. With regard to the characteristics of experts, it may be noted that 6 of the 9 interview experts currently hold an appointment of Director position; 1 - Director of Development, 1 - Director of Commerce and 1 - Sales Manager in Klaipeda city enterprises, providing with $\mathrm{KE}$ and $\mathrm{AP}$ services. Taking into account the positions, which are held by respondents, also more than 3 years experience working in the 
tourism sector and segment, which was represented by experts, it could be proposed that experts' answers to the questions are reliable, objective and reflecting the market situation.

Analysis of the results of interview with experts revealed that despite significant failings while implementing innovation in Lithuanian tourism sector the majority of respondents agree that implementation of IT innovations in Lithuanian tourism sector enhances working efficiency and improves service quality and emphasizes that their attitude towards implementation of IT innovations within the enterprise and in Lithuanian tourism sector is positive. The performed researches helped to assess the need for innovation in Klaipeda city tourism sector. According to experts the following IT innovations are used in enterprises, which they represent:

- $\quad$ smart devices (laptops, tablets, smart phones) in operating activities;

- hotel reservation system, which allows to monitor hotel occupancy;

- social networks for publication of short-term proposals;

- codes of QR (Quality Requirements);

- mobile applications and integration of them with the hotel rooms reservation system;

- $\quad$ hotels restaurants accounting systems „R-keeper“;

- additional modules, allowing reconcile foreign programs with Lithuanian ones;

- Wireless Internet access (Wi-Fi) in accommodation areas;

- $\quad$ system of online booking;

- presentment of certain groups of services in one website (reservation system of travel tickets, hotels, transportation services).

It is obvious that among listed IT innovation, which are used in KE and AP sub-sectors of Klaipeda city, there is lack of services and products, which correspond to needs expressed by users of the tourism sector and that are based on information technology, computerization, i.e. there is lack of creation of more mobile applications and virtual spaces. 